\title{
EKSISTENSI SASTRA LISAN LANGGAM SUKOHARJO MAKMUR DALAM PERPEKTIF MAHASISWA: TEORI RESEPSI RIEN T. SEGERS
}

\author{
Nurlaily Khoirun Ni'mah \\ Pendidikan Bahasa dan Sastra Indonesia, Fakultas Ilmu Budaya, Universitas Brawijaya \\ E-mail : lellynurlaily@yahoo.com
}

ABSTRAK

ABSTRACT

Penelitian ini fokus pada kajian respons mahasiswa terhadap eksistensi sastra lisan Langgam Sukoharjo Makmur, yaitu terdiri dari: (a) kebermaknaan Langgam Sukoharjo Makmur, (b) relevansi Langgam Sukoharjo Makmur dengan perkembangan zaman, (c) manfaat Langgam Sukoharjo Makmur untuk pendengar, serta (d) pelestarian Langgam Sukoharjo Makmur. Teori yang digunakan dalam penelitian ini adalah teori resensi eksperimental oleh Rien T. Segers. Data diperoleh berdasarkan angket berisi pertanyaan-pertanyaan yang disebarkan kepada para responden melalui laman pada google formulir. Adapun responden dalam penelitian ini merupakan para mahasiswa yang berdomisili di Kabupaten Sukoharjo. Data dianalisis secara kuantitatif dan kualitatif. Data kuantitatif disajikan dengan menggunakan rumus, sedangkan data kualitatif disajikan dengan cara mendeskripsikan angket yang telah diisi oleh para responden. Dari hal tersebut, dapat ditarik kesimpulan bahwa langgam Sukoharjo Makmur sudah jarang ditemukan dalam acara-acara kemasyarakatan. Namun, walaupun sudah jarang ditampilkan dalam acara-acara kemasyarakatan, mahasiswa yang merupakan generasi muda masih menanggapi secara positif adanya langgam Sukoharjo Makmur karena mereka masih menganggap langgam Sukoharjo Makmur bermakna, relevan dengan keadaan sekarang dan perkembangan zaman, mempunyai manfaat untuk para pendengarnya, dan masih memiliki kesempatan untuk melestarikannya.

Kata Kunci: respon mahasiswa, eksistensi, Langgam Sukoharjo Makmur

This research focuses on the study of student responses to the existence of Langgam Sukoharjo Makmur oral literature, which consists of: (a) the meaning of the langgam Sukoharjo Makmur style, (b) the relevance of the langgam Sukoharjo Makmur style to the times, (c) the benefits of the langgam Sukoharjo Makmur style for listeners, and (d) the preservation of the Sukoharjo Makmur style. The theory used in this study is the experimental review theory by Rien T. Segers. The data is obtained based on a questionnaire containing questions that are distributed to respondents via pages on google forms. The respondents in this study were students who live in Sukoharjo Regency. Data were analyzed quantitatively and qualitatively. Quantitative data is presented using a formula, while qualitative data is presented by describing the questionnaire that the respondents have filled in. From 
this, it can be concluded that the Sukoharjo Makmur style is rarely found in social events. However, even though it is rarely remembered in social events, students who create the young generation of Sukoharjo Makmur because they still consider the Sukoharjo Makmur style to be relevant, relevant to current conditions and current developments, have benefits for their listeners, and still have the opportunity to preserve it.

Keywords: student responses, the existence, Langgam Sukoharjo Makmur

PENDAHULUAN Musik langgam atau langgam Jawa merupakan musik yang ada di suku Jawa. Musik langgam Jawa telah menjadi bagian dari budaya musik Jawa maupun budaya musik bangsa Indonesia, khususnya di Yogyakarta (Larasati, 2014). Musik langgam ini ditampilkan oleh sejumlah penyanyi sinden dengan iringan seperangkat gamelan. Langgam Jawa ini dulunya sangat digemari oleh masyarakat Jawa, bahkan masyarakat luar Jawa pun juga banyak yang gemar mendengarkan langgam Jawa. Namun, pada era sekarang ini penggemar langgam Jawa biasanya adalah orang-orang yang sudah sepuh atau sudah lanjut usia. Seiring berkembangnya zaman, kurangnya minat oleh masyarakat muda di Indonesia dan juga masyarakat Jawa sendiri mengakibatkan keberadaan langgam Jawa semakin berkurang.

Selain dari daerah Yogyakarta, keberadaan langgam jawa juga merupakan musik yang khas dari daerah Jawa Tengah, terutama di daerah Karesidenan Surakarta. Salah satu langgam yang ada di Karesidenan Surakarta yaitu Langgam Sukoharjo Makmur. Langgam Sukoharjo Makmur merupakan suatu musik langgam yang menggambarkan identitas Kabupaten Sukoharjo, yaitu berisikan tentang tujuan Sukoharjo dan harapan agar Kabupaten Sukoharjo tetap mempertahankan hal-hal yang baik dan tetap terus memilki kemajuan.

Langgam Sukoharjo Makmur biasanya ditampilkan pada acaraacara besar kabupaten, acara kesenian, hingga acara pernikahan. Namun seiring perkembangan zaman, kurangnya minat terhadap langgam Jawa oleh masyarakat muda termasuk para mahasiswa juga mengakibatkan kurangnya eksistensi Langgam Sukoharjo Makmur di Kabupaten Sukoharjo sendiri dibandingkan musik-musik lain yang lebih modern.

Bermula dari hal-hal seperti itu, maka perlu dilakukan suatu penelitian yang berkaitan dengan respons mahasiswa terhadap eksistensi Langgam Sukoharjo Makmur. Dengan menggunakan teori resepsi oleh Rien T. Segers, penelitian ini difokuskan pada respons para mahasiswa terhadap: (a) kebermaknaan Langgam Sukoharjo Makmur, (b) relevansi Langgam Sukoharjo Makmur dengan perkembangan zaman, (c) manfaat Langgam Sukoharjo Makmur untuk pendengar, serta (d) pelestarian Langgam Sukoharjo Makmur.

METODE

Metode pada penelitian ini menggunakan metode dari Rien T. Segers, yaitu metode resepsi yang mana data didapatkan melalui penyebaran kuesioner atau angket dalam bentuk google forms yang diberikan kepada para responden. Teknik sampling yang digunakan dalam penelitian ini adalah teknik purposive sampling, di mana teknik 
purposive sampling merupakan suatu teknik pengambilan sampel yang penulis sebelumnya sudah menetapkan ciri-ciri tertentu. Responden dalam penelitian ini berjumlah 25 orang yang merupakan mahasiswa yang berdomisili atau bertempat tinggal di Kabupaten Sukoharjo. Data yang didapatkan dianalisis menggunakan analisis kualitatif. Analisis kualitatif disajikan dengan menggunakan rumus dan dengan cara deskripsi berdasarkan angket yang telah diisi oleh para responden. Adapun rumus untuk memaparkan persentasi data responden adalah sebagai berikut.

$$
\begin{aligned}
p=f / N \times 100 \% \quad \text { Keteragan }: & p=\text { Persentase } \\
& f=\text { Frekuensi } \\
& N=\text { Jumlah subjek atau responden }
\end{aligned}
$$

\section{PEMBAHASAN}

\section{Kebermaknaan Langgam Sukoharjo Makmur}

Dalam melihat eksistensi Langgam Sukoharjo Makmur dari segi kebermaknaannya di Kabupaten Sukoharjo, responden diberi pertanyaan: apakah langgam Sukoharjo Makmur menarik untuk didengar?, apakah anda mengerti dengan isi langgam Sukoharjo Makmur yang disampaikan? apakah langgam Sukoharjo Makmur memiliki tujuan?. Hasil tersebut ditampilkan pada tabel berikut.

Tabel 1. Ketertarikan terhadap Langgam Sukoharjo Makmur

\begin{tabular}{|c|c|c|c|c|}
\hline \multirow{2}{*}{ Indikator } & \multicolumn{2}{c|}{$\begin{array}{c}\text { Jawaban } \\
\text { Responden }\end{array}$} & \multicolumn{2}{c|}{ Persentase } \\
\cline { 2 - 5 } & Ya & Tidak & Ya & Tidak \\
\hline $\begin{array}{l}\text { Apakah langgam } \\
\text { Sukoharjo } \\
\text { menarik untuk didengar? }\end{array}$ & 24 & 1 & $96 \%$ & $4 \%$ \\
\hline
\end{tabular}

menjawab ya, dan 4\% responden menjawab tidak. Hal itu menunjukkan bahwa langgam Sukoharjo Makmur enak didengar. Alasan-alasan mahasiswa di Kabupaten Sukoharjo menjawab langgam Sukoharjo Makmur enak didengar adalah sebagai berikut.

Alasan pertama mahasiswa di Kabupaten Sukoharjo menjawab langgam Sukoharjo Makmur enak didengar adalah karena musik langgam yang dibawakan Karena alunan musiknya nglaras dan legendaris. Alasan kedua mahasiswa di Kabupaten Sukoharjo menjawab langgam Sukoharjo Makmur enak didengar adalah karena syair dalam langgam Sukoharjo Makmur mudah dihafal dan diingat.

Langgam Jawa memiliki tempo yang lambat dan nglaras atau beralunan lembut. Seperti yang dijelaskan oleh (Wicaksono, 2005) tentang langgam Jawa yaitu disesuaikan dengan sebagian besar populasi penelitian yaitu budaya dari suku Jawa sehingga langgam Jawa dipilih sebagai musik yang identik atau khas dengan memiliki tempo yang lamban, juga memiliki karakteristik musik yang santai, lembut, dan tenang serta memberikan efek keselarasan jiwa dan rasa. Karena pada dasarnya musik langgam memiliki tempo yang lambat dan nglaras atau beralunan lembut, dan dapat menenangkan hati para 
pendengarnya, sehingga langgam Sukoharjo Makmur enak didengar.

Pada langgam Sukoharjo Makmur terdapat naskah syair di dalamnya, di mana naskah syair merupakan suatu bentuk karya sastra yang diciptakan oleh pengarang berdasarkan hasil pikiran yang dituangkan ke dalam bentuk bahasa yang dibuatkan melodinya (Widawati: 2014). Pada langgam Sukoharjo, syair di dalamnya menggunakan bahasa Jawa yang tidak jarang ditemui oleh masyarakat Sukoharjo dalam percakapan sehari-hari. Oleh karena itu, syair langgam Sukoharjo Makmur dapat mudah dihafal, sehingga orang mudah tertarik saat mendengarkan lagu yang sudah dihafal syairnya.

Berikut ini merupakan tabel untuk melihat pemahaman mahasiswa Sukoharjo terhadap langgam Sukoharjo Makmur.

Tabel 2. Pemahaman terhadap Langgam Sukoharjo Makmur

\begin{tabular}{|l|c|c|c|c|}
\hline \multirow{2}{*}{ Indikator } & \multicolumn{2}{c|}{$\begin{array}{c}\text { Jawaban } \\
\text { Responden }\end{array}$} & \multicolumn{2}{c|}{ Persentase } \\
\cline { 2 - 5 } & Ya & Tidak & Ya & Tidak \\
\hline $\begin{array}{l}\text { Apakah anda mengerti } \\
\text { dengan is langgam }\end{array}$ & 18 & 7 & $72 \%$ & $28 \%$ \\
$\begin{array}{l}\text { Sukoharjo Makmur yang } \\
\text { disampaikan? }\end{array}$ & & & & \\
\hline
\end{tabular}

Pada tabel 2 di atas menunjukkan data bahwa $72 \%$ menjawab ya, dan $28 \%$ menjawab tidak. Hal itu menunjukkan bahwa sebagian besar mahasiswa Sukoharjo mengerti isi langgam Sukoharjo Makmur yang disampaikan. Alasan-alasan mahasiswa di Kabupaten Sukoharjo menjawab mengerti isi langgam Sukoharjo Makmur yang disampaikan adalah sebagai berikut.

Alasan pertama mahasiswa di Kabupaten Sukoharjo menjawab mengerti isi langgam Sukoharjo Makmur yang disampaikan adalah sebagian bahasa yang digunakan pada syair langgam Sukoharjo Makmur mudah dimengerti, meskipun ada beberapa kata yang sulit karena diambil dari sanskerta. Alasan kedua, karena mahasiswa memahami langgam Sukoharjo Makmur berisi tentang pencerminan dari kabupaten Sukoharjo.

Syair dalam langgam Sukoharjo Makmur mudah dimengerti karena dalam langgam Sukoharjo Makmur menggunakan bahasa Jawa yang tidak jarang ditemui oleh masyarakat Sukoharjo dalam percakapan sehari-hari. Syair langgam Sukoharjo Makmur disebut sebagai pencerminan Kabupaten Sukoharjo, karena dalam syair tersebut mengungkapkan pedoman Kabupaten Sukoharjo yaitu "MAKMUR". "MAKMUR" merupakan singkatan dari Maju, Aman, Konstitusional, Mantab, Unggul, dan Rapi. Hal itu merupakan sebuah fungsi dari langgam Sukoharjo Makmur, yaitu untuk dijadikan pedoman agar Kabupaten Sukoharjo akan selalu "MAKMUR".

Berikut ini merupakan tabel untuk melihat pentingnya langgam Sukoharjo Makmur bagi mahasiswa di Sukoharjo.

Tabel 3. Pentingnya Langgam Sukoharjo Makmur

\begin{tabular}{|l|l|l|}
\hline Indikator & $\begin{array}{c}\text { Jawaban } \\
\text { Responden }\end{array}$ & Persentase \\
\hline
\end{tabular}




\begin{tabular}{|l|c|c|c|c|}
\hline & Ya & Tidak & Ya & Tidak \\
\hline $\begin{array}{l}\text { Apakah langgam } \\
\text { Sukoharjo } \\
\text { memiliki tujuan? }\end{array}$ & 25 & 0 & $100 \%$ & $0 \%$ \\
\hline
\end{tabular}

Data pada tabel di atas menunjukkan $100 \%$ atau keseluruhan responden menjawab ya. Hal itu menunjukkan bahwa mahasiswa Sukoharjo setuju jika langgam Sukoharjo Makmur memiliki tujuan, bahkan mengetahui tujuan dari langgam Sukoharjo Makmur. Alasanalasan mahasiswa Sukoharjo menjawab langgam Sukoharjo Makmur memiliki tujuan adalah sebagai berikut.

Alasan pertama mahasiswa Sukoharjo menjawab langgam Sukoharjo Makmur memiliki tujuan adalah karena syair dalam langgam tersebut menanamkan nilai moral dalam kehidupan sehari-hari. Alasan kedua mahasiswa Sukoharjo menjawab langgam Sukoharjo Makmur memiliki tujuan adalah untuk menjaga budaya agar lebih dikenal oleh masyarakat saat ini. Alasan ketiga mahasiswa Sukoharjo menjawab langgam Sukoharjo Makmur memiliki tujuan adalah dapat mengenalkan Kabupaten Sukoharjo ke masyarakat luas.

Salah satu alasan mahasiswa menjawab langgam Sukoharjo Makmur memiliki tujuan adalah karena memiliki nilai moral. Nilai moral adalah hal baik yang disampaikan oleh pengarang untuk penikmat karyanya untuk mendidik manusia dalam kehidupan agar menjadi lebih baik. Hal ini tergantung pada keyakinan, ketertarikan, dan keinginan pengarangnya, sehingga nilai-nilai moral yang ada dapat mencakup keseluruhan kehidupannya, termasuk hubungan manusia dengan Tuhan, manusia dengan manusia, dan manusia dengan alam (Nurgiyantoro, 1998:323-324). Hal itu karena pada syair lagu mengajarkan mayarakat untuk hidup rukun, memiliki wibawa yang luhur, rapi, menjaga kebersihan, unggul martabatnya, sehingga apabila dilihat dapat membuat sengsem atau jatuh cinta kepada Kabupaten Sukoharjo dan masyarakatnya.

Alasan lain mahasiswa menjawab langgam Sukoharjo Makmur memiliki tujuan adalah karena untuk menjaga budaya agar lebih dikenal oleh masyarakat saat ini. Seperti yang kita ketahui, musik langgam merupakan salah satu budaya yang seiring berjalannya waktu semakin tidak diminati oleh generasi muda. Oleh karena itu, adanya musik langgam yang digunakan sebagai identitas Kabupaten Sukoharjo dapat dikenal oleh masyarakat Sukoharjo serta masyarakat luas, sehingga dapat mempertahankan budaya, khususnya langgam Jawa agar tetap dikenal oleh masyarakat. Dengan langgam Sukoharjo Makmur pula, masyarakat luas lebih mudah teringat dengan syair lagu dari pada hanya sebatas perkataan biasa, dan musik langgam Sukoharjo Makmur menggambarkan identitas kabupaten Sukoharjo. Hal itu dapat menjadikan langgam Sukoharjo Makmur dapat mengenalkan kepada masyarakat luas tentang Kabupaten Sukoharjo.

Relevansi Langgam Sukoharjo Makmur dengan Perkembangan Zaman

Dalam melihat eksistensi Langgam Sukoharjo Makmur dari segi relevansi dengan perkembangan zamannya di Kabupaten Sukoharjo, responden diberi pertanyaan: apakah Anda masih mendengar Langgam 
Sukoharjo Makmur hingga saat ini?, apakah isi Langgam Sukoharjo Makmur sesuai dengan keadaan zaman yang terus berkembang?, apakah generasi muda memiliki sikap simpati terhadap Langgam Sukoharjo Makmur?. Hasil tersebut ditampilkan pada tabel berikut.

Tabel 4. Penampilan Langgam Sukoharjo Makmur

\begin{tabular}{|l|c|c|c|c|}
\hline \multirow{2}{*}{ Indikator } & \multicolumn{2}{|c|}{$\begin{array}{c}\text { Jawaban } \\
\text { Responden }\end{array}$} & \multicolumn{2}{c|}{ Persentase } \\
\cline { 2 - 5 } & Ya & Tidak & Ya & Tidak \\
\hline $\begin{array}{l}\text { Apakah Anda masih } \\
\text { mendengar Langgam } \\
\begin{array}{l}\text { Sukoharjo Makmur hingga } \\
\text { saat ini? }\end{array}\end{array}$ & 9 & 16 & $36 \%$ & $64 \%$ \\
\hline
\end{tabular}

Pada tabel data di atas, sebanyak $36 \%$ responden menjawab ya dan sebanyak 64\% menjawab tidak. Hal itu menunjukkan bahwa sebagian besar mahasiswa Sukoharjo sudah jarang mendengarkan langgam Sukoharjo Makmur lagi saat ini. Berikut adalah alasan-alasan mahasiswa Sukoharjo sudah jarang mendengarkan langgam Sukoharjo Makmur lagi saat ini.

Alasan pertama mahasiswa Sukoharjo sudah jarang mendengarkan langgam Sukoharjo Makmur lagi saat ini adalah saat ini musik langgam sudah tergeser dengan budaya global. Alasan kedua mahasiswa Sukoharjo sudah jarang mendengarkan langgam Sukoharjo Makmur lagi saat ini adalah sudah jarang diperdengarkan di masyarakat umum.

Seiring dengan perkembangan zaman, musik-musik tradisional di Indonesia mulai tergeser keberadaannya. Seperti yang dijelaskan oleh Raodah (2019) bahwa sekarang ini musik tradisional belum seutuhnya diperhatikan pemangku kebijakan dalam pengembangan kesenian tradisional, sehingga minat untuk mengekspresikan diri pelaku seni musik tradisional mulai terkikis oleh tampilnya musik-musik modern yang lebih dominan di dunia generasi muda. Hal itu disebabkan bermunculannya musik-musik modern dan berbagai trend musik dari luar negeri yang lebih diminati oleh generasi muda dibandingkan dengan musik-musik tradisional di tanah air sendiri yang salah satunya adalah langgam Jawa.

Langgam Sukoharjo Makmur biasanya ditampilkan dalam acara pernikahan, namun seiring berjalannya waktu, sudah mulai jarang acara pernikahan yang menggunakan musik langgam, apalagi pada pandemi covid-19 yang terjadi saat ini yang terus meningkat di Kabupaten Sukoharjo, per 13 Desember 2020 terdapat sebanyak 2.153 orang terkonfirmasi covid-19 (Pemerintah Kabupaten Sukoharjo: 2020) yang mengakibatkan acara pernikahan dan acara kemasyarakatan lain jarang yang menggunakan tanggapan atau menampilkan hiburan. Sangat jarang langgam Sukoharjo Makmur ditampilkan lagi dalam acara kemasyarakatan. Jika ada langgam Sukoharjo Makmur ditampilkan dalam acara pernikahan, biasanya musiknya sudah bukan lagi langgam, melainkan sudah diubah menjadi bentuk musik campursari.

Berikut merupakan tabel untuk melihat relevansi langgam Sukoharjo Makmur berdasarkan pendapat mahasiswa di Sukoharjo. 
Tabel 5. Relevansi Langgam Sukoharjo Makmur

\begin{tabular}{|l|c|c|c|c|}
\hline \multirow{2}{*}{ Indikator } & \multicolumn{2}{|c|}{$\begin{array}{c}\text { Jawaban } \\
\text { Responden }\end{array}$} & \multicolumn{2}{c|}{ Persentase } \\
\cline { 2 - 5 } & Ya & Tidak & Ya & Tidak \\
\hline $\begin{array}{l}\text { Apakah isi Langgam } \\
\begin{array}{l}\text { Sukoharjo Makmur sesuai } \\
\text { dengan keadaan zaman } \\
\text { yang terus berkembang? }\end{array}\end{array}$ & 20 & 5 & $80 \%$ & $20 \%$ \\
\hline
\end{tabular}

Data pada tabel di atas terdapat $80 \%$ responden menjawab ya, dan $20 \%$ responden menjawab tidak. Hal itu menunjukkan mahasiswa Sukoharjo setuju jika langgam Sukoharjo Makmur sesuai dengan keadaan zaman yang terus berkembang. Berikut alasan-alasan mahasiswa Sukoharjo menjawab langgam Sukoharjo Makmur sesuai dengan keadaan zaman yang terus berkembang.

Alasan pertama mahasiswa Sukoharjo setuju jika langgam Sukoharjo Makmur sesuai dengan keadaan zaman yang terus berkembang adalah terletak pada isi syair dan tujuan langgam Sukoharjo Makmur yang maju, aman konstitusional, mantap, unggul, dan rapi yang merupakan suatu tujuan yang dibentuk sejak dahulu dan hingga sekarang tetap dapat dimaknai dengan baik, dan memungkinkan akan dapat menyesuiakan dengan keadaan zaman dalam jangka waktu yang panjang. Alasan kedua mahasiswa Sukoharjo setuju jika langgam Sukoharjo Makmur sesuai dengan keadaan zaman yang terus berkembang adalah dalam syairnya juga terdapat adanya cita-cita yang akan membuat orang berusaha dan berambisi untuk mewujudkannya.

Inti syair langgam Sukoharjo Makmur yang maju, aman konstitusional, mantap, unggul, dan rapi yang merupakan suatu tujuan yang dibentuk sejak dahulu dan hingga sekarang tetap dapat dimaknai dengan baik, dan memungkinkan akan dapat menyesuiakan dengan keadaan zaman dalam jangka waktu yang panjang. Dengan adanya langgam Sukoharjo Makmur, masyarakat akan dapat lebih mencintai daerahnya, sehingga memiliki keinginan untuk mencapai cita-cita yang diharapkan terwujud pada setiap harinya.

Berikut adalah tabel untuk melihat tanggapan generasi muda tentang langgam Sukoharjo Makmur.

Tabel 6. Tanggapan Generasi Muda

\begin{tabular}{|l|c|c|c|c|}
\hline \multirow{2}{*}{ Indikator } & \multicolumn{2}{c|}{$\begin{array}{c}\text { Jawaban } \\
\text { Responden }\end{array}$} & \multicolumn{2}{c|}{ Persentase } \\
\cline { 2 - 5 } & Ya & Tidak & Ya & Tidak \\
\hline $\begin{array}{l}\text { Apakah generasi muda } \\
\text { memiliki sikap simpati } \\
\text { terhadap Langam } \\
\text { Sukoharjo Makmur? }\end{array}$ & 8 & 17 & $32 \%$ & $68 \%$ \\
\hline
\end{tabular}

Data pada tebel di atas terdapat $32 \%$ responden menjawab ya, dan $68 \%$ responden menjawab tidak. Hal itu menunjukkan bahwa 
sebagian besar generasi muda tidak memiliki sikap simpati terhadap langgam Sukoharjo Makmur. Alasan-alasan mahasiswa Sukoharjo menjawab generasi muda tidak memiliki sikap simpati terhadap langgam Sukoharjo Makmur adalah sebagai berikut.

Alasan pertama mahasiswa Sukoharjo menjawab generasi muda tidak memiliki sikap simpati terhadap langgam Sukoharjo Makmur adalah karena tidak banyak generasi muda yang tau lagu Sukoharjo Makmur. Alasan kedua mahasiswa Sukoharjo menjawab generasi muda tidak memiliki sikap simpati terhadap langgam Sukoharjo Makmur adalah karena sekarang banyak anak muda yang lebih condong ke lagu yang lebih modern, seperti lagu-lagu dari luar seperti $K$-pop, jazz, dj, atau lagu-lagu luar lainnya.

Langgam Sukoharjo Makmur sudah jarang ditampilkan dalam acara-acara kemasyarakatan, sehingga banyak masyarakat yang belum mengenal langgam Sukoharjo Makmur, terutama masyarakat muda. Sebagian besar masyarakat muda yang mengetahui langgam Sukoharjo Makmur itu karena mendengar langgam Sukoharjo Makmur karena musiknya dimainkan saat pulang sekolah. Selain itu, ada pula yang mengetahui karena di sekolah diajarkan kesenian karawitan yang mempraktikkan langgam gending Sukoharjo Makmur dan hal ini sudah diterapkan di beberapa sekolah. Namun terlepas dari itu, masyarakat muda kurang, bahkan tidak mengetahui adanya langgam Sukoharjo Makmur.

Hadirnya lagu-lagu dari luar juga menyebabkan masyarakat tidak bersimpati terhadap langgam Sukoharjo Makmur. Hadirnya lagulagu dari luar tersebut tidak hanya telah menurunkan eksistensi langgam Jawa, namun eksistensi pada musik-musik daerah yang lain juga mengalami penurunan akibat beralihnya minat masyarakat muda terhadap lagu-lagu barat dan mengacuhkan musik tradisional setempat.

Manfaat Langgam Sukoharjo Makmur untuk Pendengar

Dalam melihat eksistensi Langgam Sukoharjo Makmur dari segi manfaat untuk pendengar di Kabupaten Sukoharjo, responden diberi pertanyaan: apabila Langgam Sukoharjo Makmur tidak ditampilkan saat acara besar Kabupaten Sukoharjo apakah memiliki dampak?, apakah Langgam Sukoharjo Makmur memiliki manfaat kepada yang mendengarkan?, apakah masyarakat Sukoharjo menerapkan hal-hal yang ada pada syair Langgam Sukoharjo Makmur?. Hasil tersebut ditampilkan pada tabel berikut.

Tabel 7. Pengaruh Langgam Sukoharjo Makmur

\begin{tabular}{|c|c|c|c|c|}
\hline \multirow{2}{*}{ Indikator } & \multicolumn{2}{|c|}{$\begin{array}{c}\text { Jawaban } \\
\text { Responden }\end{array}$} & \multicolumn{2}{c|}{ Persentase } \\
\cline { 2 - 5 } & Ya & Tidak & Ya & Tidak \\
\hline $\begin{array}{l}\text { Apabila Langgam Sukoharjo } \\
\text { Makmur tidak ditampilkan } \\
\text { pada acara kemasyarakatan } \\
\text { apakah memiliki pengaruh? }\end{array}$ & 22 & 3 & $88 \%$ & $12 \%$ \\
\hline
\end{tabular}

Pada tabel data di atas, terdapat $88 \%$ responden menjawab ya, dan $12 \%$ responden menjawab tidak. Hal itu menunjukkan bahwa langgam Sukoharjo Makmur memiliki pengaruh apabila tidak 
ditampilkan dalam acara-acara kemasyarakatan. Pengaruh-pengaruh berdasarkan sudut pandang mahasiswa Sukoharjo adalah sebagi berikut.

Pandangan pertama mahasiswa Sukoharjo yang menyatakan memiliki pengaruh apabila tidak ditampilkan dalam acara-acara kemasyarakatan adalah akan semakin hilang dan mungkin orang semakin tidak mendengar keberadaan langgam sukoharjo makmur. Pandangan kedua mahasiswa Sukoharjo yang menyatakan memiliki pengaruh apabila tidak ditampilkan dalam acara-acara kemasyarakatan adalah suatu acara akan kehilangan kesakralannya karena lagu Sukoharjo Makmur sudah menjadi ciri khas daerah.

Apabila tidak ditampilkan dalam acara-acara kemasyarakatan maka memiliki pengaruh akan semakin hilang dan mungkin orang semakin tidak mendengar keberadaan langgam sukoharjo makmur Hal itu terjadi karena pada saat ini sudah banyak yang tidak mengenal langgam Sukoharjo Makmur, sehingga apabila tidak dimunculkan dalam acara kemasyarakatan akan memiliki dampak semakin tidak mengenalnya masyarakat muda terhadap langgam Sukoharjo Makmur, bahkan yang sudah mengenalnya sebelumnya bisa menjadi lupa.

Karena langgam Sukoharjo Makmur merupakan lagu identitas dari Kabupaten Sukoharjo, apabila masyarakat tidak menampilkan langgam Sukoharjo Makmur dalam acara-acara kemasyarakatan maka suatu acara tersebut kurang terasa sakral karena tidak menunjukkan tradisi identitas daerah.

Berikut adalah tabel manfaat langgam Sukoharjo Makmur berdasarkan sudut pandang mahasiswa.

Tabel 8. Manfaat Langgam Sukoharjo Makmur

\begin{tabular}{|c|c|c|c|c|}
\hline \multirow{2}{*}{ Indikator } & \multicolumn{2}{|c|}{$\begin{array}{c}\text { Jawaban } \\
\text { Responden }\end{array}$} & \multicolumn{2}{c|}{ Persentase } \\
\cline { 2 - 5 } & Ya & Tidak & Ya & Tidak \\
\hline $\begin{array}{l}\text { Apakah Langgam } \\
\text { Sukoharjo } \begin{array}{l}\text { Makmur } \\
\text { memiliki manfaat kepada } \\
\text { yang mendengarkan? }\end{array}\end{array}$ & 0 & $100 \%$ & $0 \%$ \\
\hline
\end{tabular}

Pada tabel data di atas terdapat $100 \%$ responden atau seluruh responden menjawab ya. Hal ini menunjukkan bahwa menurut mahasiswa Sukoharjo langgam Sukoharjo Makmur memiliki manfaat kepada yang mendengarkan. Alasan-alasan mahasiswa Sukoharjo menjawab langgam Sukoharjo Makmur memiliki manfaat kepada yang mendengarkan adalah sebagai berikut.

Alasan pertama mahasiswa Sukoharjo menjawab langgam Sukoharjo Makmur memiliki manfaat kepada yang mendengarkan adalah sebagai penghibur dan pelipur hati. Alasan kedua mahasiswa Sukoharjo menjawab langgam Sukoharjo Makmur memiliki manfaat kepada yang mendengarkan adalah memperkenalkan budaya. Alasan ketiga mahasiswa Sukoharjo menjawab langgam Sukoharjo Makmur memiliki manfaat kepada yang mendengarkan adalah masyarakat menjadi mengetahui Sukoharjo.

Langgam yang beralunkan musik gending dengan tempo yang 
lambat menjadikan pendengar langgam Sukoharjo Makmur merasa tenang dan dapat menghibur hati. Pada keadaan masyarakat muda yang kurang mengetahui musik tradisional terutama langgam seperti saat ini, adanya langgam Sukoharjo Makmur memungkinkan untuk mengenalkan masyarakat dengan langgam yang merupakan budaya daerah sendiri. Selain itu, masih banyak masyarakat luas yang kurang mengenal Kabupaten Sukoharjo, bahkan masyarakat Sukoharjo sendiri masih banyak yang kurang mengetahui tujuan dari daerahnya sendiri. Oleh karena itu, langgam Sukoharjo Makmur dapat dimanfaatkan sebagai media untuk mengenalkan Kabupaten Sukoharjo dan tujuantujuannya kepada masyarakat.

Berikut adalah tabel penerapan syair langgam Sukoharjo Makmur berdasarkan sudut pandang mahasiswa di Sukoharjo.

Tabel 9. Penerapan Syair Langgam Sukoharjo Makmur

\begin{tabular}{|l|c|c|c|c|}
\hline \multirow{2}{*}{ Indikator } & \multicolumn{2}{|c|}{$\begin{array}{c}\text { Jawaban } \\
\text { Responden }\end{array}$} & \multicolumn{2}{c|}{ Persentase } \\
\cline { 2 - 5 } & Ya & Tidak & Ya & Tidak \\
\hline $\begin{array}{l}\text { Apakah masyarakat } \\
\text { Sukoharjo menerapkan hal- } \\
\text { hal yang ada pada syair } \\
\text { Langgam } \\
\text { Makmur? }\end{array}$ & 17 & 8 & $68 \%$ & $32 \%$ \\
\hline
\end{tabular}

Pada tabel data di atas terdapat $68 \%$ responden menjawab ya, dan 32\% responden menjawab tidak. Hal ini menunjukkan bahwa sebagian besar masyarakat Sukoharjo menerapkan hal-hal yang ada pada syair langgam Sukoharjo Makmur.

Alasan mahasiswa Sukoharjo menjawab masyarakat Sukoharjo menerapkan hal-hal yang ada pada syair langgam Sukoharjo Makmur adalah masih dijumpainya masyarakat yang ramah dan baik, serta kondisi kota yang rapi dan aman. Hal itu karena masyarakat Sukoharjo memiliki pandangan sebagai masyarakat yang ramah, daerahnya bersih, dan keadaan daerah yang aman dan jarang ditemui masyarakat kriminal, hal itu menunjukkan keadaan seperti yang ada pada syair langgam Sukoharjo Makmur.

\section{Pelestarian Langgam Sukoharjo Makmur}

Dalam melihat eksistensi Langgam Sukoharjo Makmur dari segi pelestariannya di Kabupaten Sukoharjo, responden diberi pertanyaan: apakah Langgam Sukoharjo Makmur masih perlu dilestarikan?, apakah Anda setuju apabila ada batasan usia untuk mendengarkan Langgam Sukoharjo Makmur?, apakah Anda setuju apabila Langgam Sukoharjo Makmur dijadikan sebagai bahan ajar di sekolah?. Hasil tersebut ditampilkan pada tabel berikut.

Tabel 10. Pelestarian Langgam Sukoharjo Makmur

\begin{tabular}{|l|c|c|c|c|}
\hline \multirow{2}{*}{ Indikator } & \multicolumn{2}{|c|}{$\begin{array}{c}\text { Jawaban } \\
\text { Responden }\end{array}$} & \multicolumn{2}{|c|}{ Persentase } \\
\cline { 2 - 5 } & Ya & Tidak & Ya & Tidak \\
\cline { 2 - 5 } & &
\end{tabular}




\begin{tabular}{|l|c|c|c|c|}
\hline $\begin{array}{l}\text { Apakah Langgam } \\
\text { Sukoharjo Makmur masih } \\
\text { perlu dilestarikan? }\end{array}$ & 25 & 0 & $100 \%$ & $0 \%$ \\
\hline
\end{tabular}

Pada tabel data di atas terdapat $100 \%$ responden atau keseluruhan responden menjawab ya. Hal itu menunjukkan bahwa mahasiswa sepenuhnya beranggapan perlu dilestarikannya langgam Sukoharjo Makmur. Alasan-alasan mahasiswa Sukoharjo menjawab perlu dilestarikannya langgam Sukoharjo Makmur adalah sebagai berikut.

Alasan pertama mahasiswa Sukoharjo menjawab perlu dilestarikannya langgam Sukoharjo Makmur adalah merupakan sebuah aset kebudayaan yang harus tetap dijaga. Alasan kedua mahasiswa Sukoharjo menjawab perlu dilestarikannya langgam Sukoharjo Makmur adalah agar masyarakat seterusnya tetap mengetahui tujuantujuan dari Kabupaten Sukoharjo, dan masyarakat ke depannya tetap melestarikan pedoman-pedoman yang ada di dalam syair lagu tersebut di dalam perilaku kehidupan sehari-hari supaya ciri khas Kabupaten Sukoharjo tidak luntur.

Langgam Sukoharjo Makmur merupakan sebuah aset kebudayaan. Seperti yang dijelaskan oleh Rahma (2014), kebudayaan merupakan suatu aset yang dimiliki oleh bangsa yang harus terus dijaga dan dilestarikan. Langgam Sukoharjo Makmur merupakan kebudayaan Indonesia yang merupakan aset bangsa, oleh karena itu kita perlu menjaga eksistensi langgam Sukoharjo Makmur agar dapat selalu lestari. Seiring perkembangan zaman boleh menerima hal-hal baru yang lebih modern, namun kekayaan budaya yang ada sejak dahulu, seperti langgam Jawa harus tetap lestari hingga kehidupan yang akan datang dan seterusnya agar tetap terjaga aset kebudayaan yang dimiliki.

Berikut merupakan tabel untuk melihat batasan usia langgam Sukoharjo Makmur menurut pendapat mahasiswa di Kabupaten Sukoharjo.

Tabel 11. Batasan Usia Langgam Sukoharjo Makmur

\begin{tabular}{|c|c|c|c|c|}
\hline \multirow{2}{*}{ Indikator } & \multicolumn{2}{|c|}{$\begin{array}{c}\text { Jawaban } \\
\text { Responden }\end{array}$} & \multicolumn{2}{c|}{ Persentase } \\
\cline { 2 - 5 } & Ya & Tidak & Ya & Tidak \\
\hline $\begin{array}{l}\text { Apakah Anda setuju apabila } \\
\text { ada batasan usia untuk } \\
\text { mendengarkan Langgam } \\
\text { Sukoharjo Makmur? }\end{array}$ & 5 & 20 & $20 \%$ & $80 \%$ \\
\hline
\end{tabular}

Pada tabel data di atas terdapat $20 \%$ responden memilih ya, dan $80 \%$ responden memilih tidak. Hal itu menunjukkan bahwa mahasiswa Sukoharjo tidak setuju apabila ada batasan usia untuk mendengarkan Langgam Sukoharjo Makmur.

Alasan mahasiswa Sukoharjo tidak setuju apabila ada batasan usia untuk mendengarkan Langgam Sukoharjo Makmur adalah karena pesan atau isi dari langgam ini bisa diterima untuk semua usia, termasuk anak-anak. Tidak adanya unsur sara dan kekerasan 
menjadikan langgam Sukoharjo Makmur aman untuk didengar oleh semua kalangan dan semua usia. Hal itu seperti yang dijelaskan oleh Endraswara (2009:6) lagu untuk anak-anak adalah lagu yang memiliki cerminan etika yang luhur, sederhana, dan mencerminkan hal-hal baik yang dekat dengan lingkungannya. Berdasarkan hal tersebut, justru merupakan hal yang baik apabila langgam Sukoharjo Makmur diperdengarkan kepada anak-anak, karena syair di dalam langgam Sukoharjo Makmur terdapat pesan-pesan moral agar berperilaku yang baik dalam kehidupan sehari-hari.

Berikut adalah tabel untuk melihat respon mahasiswa mengenai langgam Sukoharjo yang dijadikan bahan ajar.

Tabel 12. Langgam Sukoharjo Makmur Dijadikan Bahan Ajar

\begin{tabular}{|l|c|c|c|c|}
\hline \multirow{2}{*}{ Indikator } & \multicolumn{2}{c|}{$\begin{array}{c}\text { Jawaban } \\
\text { Responden }\end{array}$} & \multicolumn{2}{c|}{ Persentase } \\
\cline { 2 - 5 } & Ya & Tidak & Ya & Tidak \\
\hline $\begin{array}{l}\text { Apakah Anda setuju } \\
\text { apabila } \\
\begin{array}{l}\text { Sukoharjo Langgam } \\
\text { dijadikan sebagai bahan } \\
\text { ajar di sekolah? }\end{array}\end{array}$ & 25 & 0 & $100 \%$ & $0 \%$ \\
\hline
\end{tabular}

Pada tabel data di atas terdapat $100 \%$ responden atau keseluruhan responden menjawab ya. Hal itu menunjukkan bahwa mahasiswa Sukoharjo sepenuhnya setuju apabila langgam Sukoharjo Makmur dijadikan bahan ajar di sekolah. Alasan-alasan mahasiswa Sukoharjo setuju apabila Langgam Sukoharjo Makmur dijadikan sebagai bahan ajar di sekolah adalah sebagai berikut.

Alasan pertama mahasiswa Sukoharjo setuju apabila Langgam Sukoharjo Makmur dijadikan sebagai bahan ajar di sekolah adalah sekolah merupakan salah satu media yang baik untuk edukasi dapat mengenalkan langgam Sukoharjo Makmur bagi masyarakat muda, sehingga dengan demikian langgam Sukoharjo Makmur dapat dilestarikan melalui media ini. Alasan kedua mahasiswa Sukoharjo setuju apabila Langgam Sukoharjo Makmur dijadikan sebagai bahan ajar di sekolah adalah untuk melestarikan budaya karawitan. Alasan ketiga mahasiswa Sukoharjo setuju apabila Langgam Sukoharjo Makmur dijadikan sebagai bahan ajar di sekolah adalah agar tertanam budaya dan berbudi pekerti luhur.

Sekolah merupakan tempat pendidikan formal yang bertujuan untuk memberikan pengetahuan, kemampuan siswa agar siswa dapat memperoleh taraf hidup yang lebih baik untuk ke depannya (Irwandi: 2016). Sekolah merupakan salah satu media yang baik untuk edukasi dapat mengenalkan langgam Sukoharjo Makmur bagi masyarakat muda, sehingga dengan demikian langgam Sukoharjo Makmur dapat dilestarikan melalui media ini. Seperti yang kita ketahui, musik langgam merupakan musik yang diiringi dengan gending, seperti halnya langgam Sukoharjo Makmur. Pada sebagian besar sekolah di Kabupaten Sukoharjo terdapat alat musik gamelan untuk pembelajaran seni karawitan, namun banyak juga sekolah yang kurang menggunakan 


\section{SIMPULAN}

alat musik gamelan tersebut. Sehingga budaya seni karawitan akan tetap lestari apabila langgam Sukoharjo Makmur digunakan dalam pembelajaran seni di sekolah. Sekolah merupakan tempat yang kuat untuk menanamkan pendidikan. Di dalam langgam Sukoharjo Makmur terdapat pesan-pesan moral yang berguna untuk kehidupan sehari-hari agar berperilaku baik dan cinta akan daerah. Apabila langgam Sukoharjo Makmur diajarkan di sekolah, akan sangat memungkinkan pesan-pesan moral yang ada di dalam langgam Sukoharjo Makmur tersebut dapat tersampaikan dengan baik kepada masyarakat muda.

Berdasarkan pembahasan di atas, dapat ditarik kesimpulan bahwa langgam Sukoharjo Makmur sudah jarang ditemukan dalam acara-acara kemasyarakatan dan banyak generasi muda yang tidak mengetahui adanya langgam Sukoharjo Makmur. Namun, walaupun sudah jarang ditampilkan dalam acara-acara kemasyarakatan, mahasiswa yang merupakan generasi muda masih menanggapi secara positif adanya langgam Sukoharjo Makmur karena mereka masih menganggap langgam Sukoharjo Makmur bermakna, relevan dengan keadaan sekarang dan perkembangan zaman, mempunyai manfaat untuk para pendengarnya, dan masih memiliki kesempatan untuk melestarikannya.

\section{DAFTAR PUSTAKA}

Ananda, Sisca Dwi. 2013. Studi Estetika Eksperimental: Tanggapan Pembaca Akademik Terhadap Drama Der Zerbrochene Krug Karya Heinrich Von Kleist. Yogyakarta.

Andriani, Tuti. 2015. Revitalisasi Naskah Syair: Sebuah Solusi dalam Pengembangan Kreativitas Mahasiswa untuk Mencintai Budaya Lokal. Pekanbaru.

Armawi, Armaidy. 2011. Eksistensi Manusia dalam Filsafat Sören Kierkegaard. Yogyakarta.

Didipu, Herman. 2020. Respons Masyarakat terhadap Eksistensi Sastra Lisan Palebohu: Studi Pendahuluan Berdasarkan Teori Resepsi Rien T. Segers. Gorontalo.

Endraswara, S. 2009. Metodologi penelitian folklor. Yogyakarta: Medpress.

Hasanah, Uswatun. 2017. Nilai Moral dalam Sāq Al-bambū Karya Sa 'ūd AlSan 'üsī. Yogyakarta.

Irwandi, Satria, dkk. 2016. Peran Sekolah dalam Menumbuhkembangkan Perilaku Hidup Sehat pada Siswa Sekolah Dasar. Malang.
Larasati, S. 2014. Gaya Vokal Waldjinah Pada Langgam Keroncong. Bandung.

Nurgiyantoro, Burhan. 1998. Teori Pengkajian Fiksi. Yogyakarta.

Pemerintah Kabupaten Sukoharjo. 2020. COVID-19 Sukoharjo. Sukoharjo. Dalam

https://experience.arcgis.com/experien ce/ce68569f4e9e4008ba4e15aeb77928 95/page/page_0/.13 Desember.

Rahma, Nur. 2014. Tinjauan Sosiokultural Makna Filosofi Tradisi Upacara Adat Maccera Manurung sebagai Aset Budaya Bangsa yang Perlu Dilestarikan. Makassar.

Raodah. 2019. Eksistensi dan Dinamika Pertunjukan Musik Tradisional Mandar di Kabupaten Polman Sulawesi Barat. Makassar.

Segers, Rien T. 2000. Evaluasi Teks Sastra: Sebuah Penelitian Eksperimental Berdasarkan Teori Semiotik dan Estetika Resepsi. Penerjemah Sumianto Sayuti. Yogyakarta : Adicita Karya Nusa.

Wicaksono, S. 2005. Simponi Musik Jawa Bercita Rasa Keselarasan Hidup. Jakarta: EGC. Dalam 
http://www.jawapalace.org November.

Widawati, Rika. 2014. Syair Lagu dalam Pengajaran Sastra. Bandung. 